\title{
Strict thermal threshold identified by quantitative PCR in the sponge Rhopaloeides odorabile
}

\author{
Raffaella Pantile*, Nicole Webster \\ Australian Institute of Marine Science, 4810 Townsville, Queensland, Australia
}

\begin{abstract}
In light of increasing sea surface temperatures, quantifying the expression of stressinducible genes in coastal organisms is imperative to identify early biomarkers of thermal stress. In the present study we developed a quantitative PCR (qPCR) assay to test the molecular response to heat stress in the Great Barrier Reef sponge Rhopaloeides odorabile. Suitable reference genes (coding for $\alpha$-tubulin, 28S rRNA and ubiquitin) were identified among 5 candidates and then used to normalise expression of target genes (actin-related protein, calmodulin, ferritin, ubiquitin-conjugating enzyme, heat shock protein 90 [Hsp90] and heat shock protein 40 [Hsp40]) in samples exposed to high temperatures $\left(31\right.$ and $32^{\circ} \mathrm{C}$ ) for $1,3,14$ and $15 \mathrm{~d}$. A rapid down-regulation of most genes (actinrelated protein, ferritin, calmodulin and Hsp90) was observed at both temperatures within $24 \mathrm{~h}$, indicating an initial shut-down of the sponge's molecular systems in response to thermal stress. The increased expression of $\mathrm{Hsp} 40$ and $\mathrm{Hsp} 90$ in sponges at $32^{\circ} \mathrm{C}$ after 1 and $3 \mathrm{~d}$ respectively indicates an activation of the heat shock response system and is consistent with their role as chaperones for directing degraded proteins to proteolysis, this last process being sustained by an induction of the ubiquitin-conjugating enzyme gene at this temperature. While sponges kept at $32^{\circ} \mathrm{C}$ only survived for the first $3 \mathrm{~d}$, none of the genes in sponges kept at $31^{\circ} \mathrm{C}$ were significantly different from those in the $27^{\circ} \mathrm{C}$ controls after $14 \mathrm{~d}$. This indicates a very strict thermal threshold for $R$. odorabile between 31 and $32^{\circ} \mathrm{C}$ and is consistent with previous findings based on sponge necrosis and symbiotic disruptions in this species.
\end{abstract}

KEY WORDS: qPCR · Quantitative PCR · Thermal stress · Porifera · Great Barrier Reef Resale or republication not permitted without written consent of the publisher

\section{INTRODUCTION}

Coral reefs are among the most biologically productive, diverse and economically important habitats, but they are threatened by an increasing number of sources, including climate change. It has been estimated that over the next $50 \mathrm{yr}$, surface ocean temperatures will exceed the temperature conditions under which coral reefs have flourished over the past 500000 yr (Hughes et al. 2003) and drive corals to extinction in <100 yr (Hoegh-Guldberg 1999, Kleypas et al. 1999, Hoegh-Guldberg et al. 2007). Other more optimistic views predict that the long-term responses of coral reefs to climate change will be dictated by the capacity of reef organisms to adapt or acclimatise to warmer temperatures (Baker 2001, Baker et al. 2004,
Rowan 2004). In order to predict the ability of reef organisms to adapt to changing environmental conditions, we need to enhance our understanding of their responses to stress, particularly at the molecular level. To date, research on thermal-stress responses in reef organisms has focused on corals and their symbiotic zooxanthellae, and only a few studies have assessed this response in other phyla (Kassahn et al. 2007, López-Legentil et al. 2008). This constitutes an important gap in coral reef biology, as other keystone reef organisms, especially invertebrates, remain largely under-studied (Przeslawski et al. 2008).

Porifera (sponges), are benthic filter-feeders and a critical component of coral reefs due to their abundance and diversity and their role in benthic-pelagic coupling (Bell 2008). Despite the ecological impor- 
tance of Porifera, the effect of thermal stress on sponges has rarely been investigated, particularly at the molecular level. The few studies published on this topic include a thermal-stress experiment in which Western blotting was utilised to show that the marine sponge Suberites domuncula expresses a $45 \mathrm{kDa}$ polypeptide after heat treatment (Bachinski et al. 1997). Moreover, a drop in trehalose (a disaccharide that can protect yeast from temperature stress as shown by Hottiger et al. 1987 and Eleutherio et al. 1993), a reduction in the activity of the detoxifying and antioxidant enzyme glutathione-S-transferase (GST) and a concomitant decrease of its substrate glutathione (GSH) were recorded in the same specimens. In heatand cold-stressed Geodia cydonium, an increased transcription of the heat shock protein 70 (Hsp70) gene and a reduction of the Rab GDP dissociation inhibitor (GDI) mRNA (a key element in the intracellular traffic system) were observed using Northern blotting (Krasko et al. 1997). These findings indicate the presence of active heat-stress protection mechanisms in sponges at the cellular level. More recently, 2 studies have utilised quantitative PCR (qPCR) to accurately quantify the stress response. The molecular response of the sponge Xestospongia muta undergoing fatal and cyclic bleaching in the field and during experimental thermal and salinity stress was assessed by measuring the abundance of the chaperone $H s p 70$ gene transcript (López-Legentil et al. 2008) with qPCR. While Hsp70 mRNA levels were significantly higher in the fatally bleached sponges than in normal tissues, expression of the $H$ sp 70 gene indicated that cyclic bleaching did not cause any additional stress. Hsp70 gene expression varied over time in the salinity and temperature treatments, but while sponges were able to adjust to osmotic changes, higher-than-normal temperatures caused a significant increase in $H s p 70$ transcript levels and a subsequent drop likely due to metabolic failure. The only other study to assess sponge stress responses using qPCR was an analysis of the immunological status of 2 populations of $S$. domuncula by comparing the allograft inflammatory factor-1 (AIF-1) transcript levels in specimens from different sites (Schröder et al. 2004).

qPCR is a highly sensitive method for accurately quantifying mRNA abundance levels in a variety of organisms (Perkins \& Lotufo 2003, Bustin et al. 2009, Mieog et al. 2009, Jarosová \& Kundu 2010). This technique is now routinely used in studies of marine ecology (Watanabe \& Hamamura 2003, Hofmann \& Place 2007, Smith \& Osborn 2009), and guidelines have been developed to instruct researchers on how to optimally perform and interpret qPCR experiments (Bustin et al. 2009). An essential component of a reliable qPCR assay is the data normalisation: this process controls and corrects for experimental variations that may occur during the extraction, reverse transcription and amplification of RNA (Bustin 2000, 2002). The qPCR data can be normalised against sample size, total RNA concentration or genomic DNA. However, the use of reference genes as an internal control is highly advantageous as they have been exposed to the same treatment as the target genes and represent the cumulative error of the entire process (Huggett et al. 2005). The ideal reference gene is expected to maintain stable expression between experimental groups due to the fundamental function it plays in the cell (Ransbotyn \& Reusch 2006). Unfortunately, a universal reference gene that is stably expressed in all tissues and across different treatments does not exist (Haller et al. 2004) and most importantly, recent studies have shown that many of the most commonly used reference genes, such as those coding for glyceraldehyde-3-phosphate dehydrogenase (GAPDH), $\beta$-actin (ACTB), or ribosomal proteins (18S or $28 \mathrm{~S}$ ), do not actually maintain a constant level of expression across all tissues and under different experimental conditions. For this reason, it is necessary to validate the stability of candidate reference genes prior to their use in normalising the target genes in specific experimental designs (Suzuki et al. 2000, Vandesompele et al. 2002, Nicot et al. 2005, Gutierrez et al. 2008).

In a previous study, the effect of elevated seawater temperature on microbial symbiosis within the marine sponge Rhopaloeides odorabile was assessed (Webster et al. 2008). Sponges were exposed to temperatures ranging between 27 and $33^{\circ} \mathrm{C}$. While no differences in bacterial community composition or sponge health were detected in treatments between 27 and $31^{\circ} \mathrm{C}$, sponges exposed to $33^{\circ} \mathrm{C}$ exhibited a loss of microbial symbionts within $24 \mathrm{~h}$ and major cellular necrosis within $3 \mathrm{~d}$. In order to determine the molecular-level sponge response to thermal stress, we have developed a qPCR assay to profile the expression levels of 6 genes that have previously been reported to be involved in the stress response (Feder \& Hofmann 1999, Schroth et al. 2005, Schallreuter et al. 2007, Császár et al. 2009): the genes encoding for (1) ubiquitin-conjugating enzyme (UbC), which makes part of the ubiquitinproteasome pathway responsible for the selective degradation of misfolded or damaged proteins produced during heat shock or oxidative stress and which cannot be repaired by the heat shock protein (HSP) molecular chaperones (Glickman \& Ciechanover 2002, Goldberg 2003); (2) actin-related protein (arp2/3), which plays a central role in the control of actin polymerisation and cytoskeletal function (Machesky \& Gould 1999); (3) ferritin (FER), a highly conserved and ubiquitous iron-sequestering protein that provides protection against the catalysis of deleterious oxidation of biomolecules by $\mathrm{Fe}^{2+}$, playing a fundamental role in 
protecting the cell from damage due to oxidative stress (Torti et al. 1988, Halliwell \& Gutteridge 1989, Harrison \& Arosio 1996); (4) calmodulin (CaM), a Ca ${ }^{2+}$-binding protein that serves to maintain homeostatic balance and mediate the signal-transduction cascade by binding to and altering the activity of a variety of other proteins (Zielinski 1998); down-regulation of CaM has previously indicated oxidative and heat stress in the coral Montastraea faveolata (De Salvo et al. 2008); (5) heat shock protein 40 (Hsp40), which functions in parallel with $H s p 70$ to promote protein folding, transport and degradation (Li et al. 2009); and (6) heat shock protein 90 (Hsp90), an abundant and highly conserved molecular chaperone that contributes to the folding, maintenance of structural integrity and proper regulation of many cytosolic proteins (Picard 2002). In addition, we rigorously assessed the suitability of 5 candidate reference genes that are commonly adopted as internal controls in gene-expression profiling studies.

\section{MATERIALS AND METHODS}

cDNA clone library construction and primer design. In April 2008, 9 specimens of Rhopaloeides odorabile were collected off Pelorus Island in the Great Barrier Reef $\left(18^{\circ} 32.710^{\prime} \mathrm{S}, 146^{\circ} 29.273^{\prime} \mathrm{E}\right)$. Each sponge was placed in a separate sealed bag and quickly transported to the laboratory ( $15 \mathrm{~min})$. Three replicate specimens per treatment were each exposed to heat stress $\left(33^{\circ} \mathrm{C}\right.$, salinity 35$)$, salinity stress $\left(27^{\circ} \mathrm{C}\right.$, salinity 25) or ambient (control) conditions $\left(27^{\circ} \mathrm{C}\right.$, salinity 35 ) for $8 \mathrm{~h}$ in aquaria with static, but aerated water. The samples from the heat-stress and salinity-stress treatments were combined prior to preparation of cDNA clone libraries (1 of treated sponges and 1 of control sponges). Small pieces of the stressed sponges were ground together in liquid nitrogen using a mortar and pestle to make a single homogenate. The mRNA was extracted from control and treated homogenates using the DynaBeads mRNA Direct kit (Invitrogen) following the manufacturer's instructions. Equal amounts of mRNA ( $27 \mathrm{ng})$ were reverse-transcribed with a Creator SMART cDNA Library Construction Kit (Clontech) and Prime Script Reverse Transcriptase (Takara) following the manufacturer's instructions. The cDNA $(2 \mu \mathrm{l})$ was further amplified using the following protocol and primers: $95^{\circ} \mathrm{C}$ for $1 \mathrm{~min}, 24$ cycles at $95^{\circ} \mathrm{C}$ for $15 \mathrm{~s}$ and $68^{\circ} \mathrm{C}$ for $6 \mathrm{~min}$; CDS III/3' PCR Primer $5^{\prime}$-ATT CTA GAG GCC GAG GCG GCC GAC ATG-d(T)30N$1 \mathrm{~N}-3^{\prime}$ and 5' PCR Primer 5'-AAG CAG TGG TAT CAA CGC AGA GT-3'. PCR products were digested with Proteinase K and SfiI and successively size-fractionated following the Creator SMART cDNA Library Construction Kit instructions. The profile of the fractions was checked on a $1.1 \%$ agarose-ethidium bromide (EtBr) gel $(3 \mu \mathrm{l}$ of each fraction were run at $150 \mathrm{~V}$ for $10 \mathrm{~min})$. For each library, 6 fractions containing cDNA were obtained and, according to manufacturer's instructions, the first 4 fractions containing cDNA within the correct size range were selected and pooled together, to be successively ligated into dephosphorylated pDNR-LIB vector using 3 different ratios of cDNA to the vector. A total of 6 ligation reactions ( 3 for the control-sponge library and 3 for the treated-sponge library) were sent to the Australian Genome Research Facility (AGRF, Brisbane, Australia) to be separately transformed into electrocompetent Escherichia coli cells and sequenced using M13 primers.

Sequences were edited with Sequencher v. 4.7 (Gene Codes): those lacking a polyA ${ }^{+}$tail and/or having poor-quality files were discarded and the vector was trimmed to isolate the actual genes. Putative gene sequences were then compared to GenBank sequences using the BLAST tool for a functional identification. A total of 116 unique genes were identified, from which 5 commonly used candidate reference genes (GenBank accession nos. GU951541, GU951542, GW667522, GW667523 and GW667524) and 6 target genes (GenBank accession nos. HS097565 to HS097570) were selected. The qPCR primers were designed using the open-access online software Primer3 (http://biotools.umassmed.edu/bioapps/primer3_www. cgi) (Rozen \& Skaletsky 1999) according to guidelines given by Wang \& Seed (2006). The presence of secondary structures such as primer-dimers, cross dimers and hairpins was checked using NetPrimer (www.premierbiosoft.com/netprimer/index.html). Primers were synthesised by Sigma-Aldrich. Primer sequences are given in Table 1.

Temperature-stress experiment. Sponges were collected at Pelorus Island on the Great Barrier Reef, Australia $\left(18^{\circ} 32.710^{\prime} \mathrm{S}, 146^{\circ} 29.273^{\prime} \mathrm{E}\right)$ in July 2009. Briefly, 6 donor sponges were cut into a total of 100 clones $\left(\sim 15 \mathrm{~cm}^{3}\right)$ and randomly transferred to plastic racks without tagging for further identification. The sponge clones were allowed to heal on the reef for 12 wk before collection and transportation to the indoor temperature-controlled aquarium at the Australian Institute of Marine Science, Townsville (Queensland, Australia). The experimental design incorporated 3 temperatures $\left(27,31\right.$ and $32^{\circ} \mathrm{C}_{i}$ range: $\pm 0.2{ }^{\circ} \mathrm{C}$ ) in 3 replicate $30 \mathrm{l}$ flow-through aquaria per temperature, each holding 8 sponge clones. The experiment was conducted as described previously (Webster et al. 2008), randomly sampling 1 clone from each replicate tank per temperature at $t=0,1,3,14$ and $15 \mathrm{~d}$. After $3 \mathrm{~d}$, the sponges in the $32^{\circ} \mathrm{C}$ treatment displayed signs of cell discharge and necrosis and by the 4th day all sponges in this treatment were considered dead. In the 
Table 1. Rhopaloeides odorabile. Forward (f) and reverse (r) primers used in the quantitative PCR assay to amplify target and reference genes in $R$. odorabile. e: reaction efficiency, rLSU: 28S rRNA, Ub: ubiquitin, a-tub: $\alpha$-tubulin, act68: actin, mtLSU: mitochondrial rRNA, arp2/3: actin-related protein, CaM: calmodulin, FER: ferritin, Hsp40: heat shock protein 40, Hsp90: heat shock protein 90, UbC: ubiquitin-conjugating enzyme

\begin{tabular}{|c|c|c|c|c|c|}
\hline $\begin{array}{l}\text { Gene coding } \\
\text { for }\end{array}$ & $\begin{array}{l}\text { GenBank } \\
\text { accession no. }\end{array}$ & Function & Primer sequence $5^{\prime}-3^{\prime}$ & $\begin{array}{l}\text { Length } \\
\text { (bp) }\end{array}$ & e \\
\hline rLSU & GU951542 & $\begin{array}{l}\text { Structural component, large } \\
\text { ribosomal subunit }\end{array}$ & $\begin{array}{l}\text { f: TGTAGCCCGAAGCAGTTTT } \\
\text { r: TTCATCCCGCATCGCCAGTT }\end{array}$ & 184 & 1.06 \\
\hline $\mathrm{Ub}$ & GW667524 & Protein degradation & $\begin{array}{l}\text { f: TCAGCAACGATTGATTTTCG } \\
\text { r: ACGCAGCCGTAGCACTAGAT }\end{array}$ & 106 & 1.01 \\
\hline a-tub & GW667522 & Microtubule constituent & $\begin{array}{l}\text { f: ATTGGAGGGGGAGATGATT } \\
\text { r: TGACCACGGGCATAGTTGTT }\end{array}$ & 196 & 1.06 \\
\hline act68 & GW667523 & Cytoskeleton component & $\begin{array}{l}\text { f: GCATGGAGAAGAGCTACGAA } \\
\text { r: AAGAAGGATGGCTGGAACAA }\end{array}$ & 97 & 1.09 \\
\hline mtLSU & GU951541 & $\begin{array}{l}\text { Structural component, large } \\
\text { ribosomal subunit }\end{array}$ & $\begin{array}{l}\text { f: CGAATGCCTCACTGTCTCAA } \\
\text { r: CCCCAACTAAACTGTCTGTAT }\end{array}$ & 139 & 0.9 \\
\hline $\operatorname{arp} 2 / 3$ & HS097565 & Control of actin polymerisation & $\begin{array}{l}\text { f: ACCCGAGGTTGAAGTGAAGA } \\
\text { r: CTATCTCATCCGCCTGTTT }\end{array}$ & 142 & 1.04 \\
\hline $\mathrm{CaM}$ & HS097566 & $\mathrm{Ca}^{2+}$ binding, signal transduction & $\begin{array}{l}\text { f: GGGTGTTCGTAATCTTGTT } \\
\text { r: ATCGTACCGTCTCCATCCTT }\end{array}$ & 132 & 1.02 \\
\hline FER & HS097567 & Iron sequestering & $\begin{array}{l}\text { f: TCTTTGCTGTGCCAGTGAGTA } \\
\text { r: CGCATTCAGGGTGGTAGTT }\end{array}$ & 133 & 0.9 \\
\hline Hsp40 & HS097568 & Molecular chaperone & $\begin{array}{l}\text { f: CGCATTCAGGGTGGTAGTT } \\
\text { r: CTAAGTCCCGACCACGTTTC }\end{array}$ & 200 & 1.02 \\
\hline Hsp90 & HS097569 & Molecular chaperone & $\begin{array}{l}\text { f: TGGCGGTTCCTTTACAGTTC } \\
\text { r: ACACCTCCTTGTCACGTTCC }\end{array}$ & 200 & 0.97 \\
\hline $\mathrm{UbC}$ & HS097570 & Protein degradation via the proteasome & $\begin{array}{l}\text { f: AGCGACAATCATGGGACCT } \\
\text { r: GGATAGTCCGTTGGAAAGT }\end{array}$ & 89 & 1.06 \\
\hline
\end{tabular}

remaining treatments, temperatures were maintained for the first $14 \mathrm{~d}$ and then all temperatures were returned to $27^{\circ} \mathrm{C}$ for the final $24 \mathrm{~h}$ of the experiment as a recovery period. Samples were immediately snapfrozen in liquid nitrogen after collection, and maintained at $-80^{\circ} \mathrm{C}$ for no longer than a month before mRNA extraction and analysis.

RNA extraction and cDNA synthesis. RNA was extracted from all samples $\left(1 \mathrm{~cm}^{3}\right)$ using the RNeasy Plant Mini kit (Qiagen) following the manufacturer's instructions. DNA contamination was eliminated with the DNA-free kit (Ambion). RNA quality, integrity and purity was confirmed by gel electrophoresis (the $18 \mathrm{~S}$ and $28 \mathrm{~S}$ bands were clearly visible) and by examining the 260:280 ratio (ranging from 1.92 and 2.06) using a Nanodrop spectrophotometer (Thermoscientific). The final RNA concentration was measured with a Nanodrop. First-strand cDNA synthesis was carried out using the Superscript Vilo cDNA synthesis kit (Invitrogen): the $20 \mu \mathrm{l}$ reaction, containing $4 \mu \mathrm{l}$ of $5 \times$ Vilo Reaction mix, $2 \mu$ of $10 \times$ SuperScript Enzyme mix including random primers, $1 \mu \mathrm{g}$ RNA and RNase-free water, was incubated at $25^{\circ} \mathrm{C}$ for $10 \mathrm{~min}$, at $42^{\circ} \mathrm{C}$ for $80 \mathrm{~min}$ and terminated after $85^{\circ} \mathrm{C}$ for $5 \mathrm{~min}$. All cDNAs were diluted to $1 \mathrm{ng}^{-1} \mathrm{l}^{-1}$ (RNA equivalent concentration) and aliquots were stored at $-20^{\circ} \mathrm{C}$.
qPCR assay optimisation. Amplification specificity and efficiency: PCR efficiency was assessed using the standard curve method: cDNA from control and treated samples were pooled together and 10-fold serial dilutions starting from $1 \mathrm{ng} \mathrm{ul}^{-1}$ to $10^{-4} \mathrm{ng} \mathrm{ul}^{-1}$ cDNA (RNA equivalent concentration) were run in duplicate in a Rotorgene 3000 (Corbett Research) using $250 \mathrm{nM}$ primers (final concentration). All tubes, tips, qPCR tubes and nuclease-free water aliquots were UVsterilised for $15 \mathrm{~min}$ before use. The PCR reaction consisted of $7.5 \mu \mathrm{l}$ of $2 \times$ SensiMix NoRef (Quantace), $0.3 \mu \mathrm{l}$ of $50 \times$ Sybr Green I solution (Quantace), $0.375 \mu \mathrm{l}$ of each primer (forward and reverse, at $10 \mu \mathrm{M}$ intial concentration), $2 \mu$ l of template cDNA and $4.45 \mu \mathrm{l}$ nuclease-free water for a final volume of $15 \mu \mathrm{l}$. Master mix and cDNA template serial dilutions were prepared manually and dispensed in a robotic liquid-handling workstation CAS-1200 (Corbett Robotics). During each run, 2 no-template controls (NTC) were added to check for reagent contamination. Another reaction was run at the same time and with the same mix, with cDNA replaced by RNA in order to check for genomic DNA contamination. Cycling conditions were as follows: $10 \mathrm{~min}$ at $95^{\circ} \mathrm{C}, 35$ cycles of $15 \mathrm{~s}$ at $95^{\circ} \mathrm{C}, 20 \mathrm{~s}$ at $55^{\circ} \mathrm{C}, 20 \mathrm{~s}$ at $72^{\circ} \mathrm{C}$. The specificity of amplification was verified by melting curve analysis $\left(50\right.$ to $99^{\circ} \mathrm{C}$ ). In addi- 
tion, agarose gel electrophoresis followed by ethidium bromide staining was performed to confirm correct size of the qPCR products. Reaction efficiency (e) was calculated from the slope $(\mathrm{m})$ of the standard curve $(\mathrm{e}=$ $\left.\left[10^{(-1 / \mathrm{m})}\right]-1\right)$ obtained by plotting the quantification cycle $\left(\mathrm{C}_{\mathrm{q}}\right)$ versus the log of the template concentration (after manually setting the threshold value with the Rotorgene 6.1 software).

Validation of reference genes: The expression stability of the 5 candidate reference genes was tested using biological triplicates and technical duplicates for sponge clones sampled after $0,1,3,14$ and $15 \mathrm{~d}$ at the 3 different temperatures $\left(27,31\right.$ and $\left.32^{\circ} \mathrm{C}\right)$. Cycling conditions and reaction mixes were as described in 'Amplification specificity and efficiency' above. Data were collected as $\mathrm{C}_{\mathrm{q}}$ values obtained after setting the threshold across the exponential phase of the amplification curve. The average $C_{q}$ of the technical replicates was calculated and transformed to quantities (using standard curves) as input data required by the NormFinder algorithm. This software (available as a Microsoft Excel add-in at www.mdl.dk/publicationsnormfinder.htm) determines the stability of gene expression by evaluating the variation in expression within treatments compared to variation between treatments: low variation between treatments signifies stable expression. The software developers recommend evaluating the stability of at least 5 candidate reference genes and a minimum of 2 genes to assure reliable normalisation (Andersen et al. 2004).

qPCR assay. A total of 6 target genes (encoding for arp2/3, CaM, Hsp40, Hsp90, FER and UbC) covering a range of functions in the cell were chosen to assess the response of Rhopaloeides odorabile to thermal stress. The expression of the target and reference genes was tested with biological triplicates ( 3 clones, 1 from each tank per temperature) and technical duplicates for sponge clones sampled after $0,1,3,14$ and $15 \mathrm{~d}$ at the 3 different temperatures $\left(27,31\right.$ and $\left.32^{\circ} \mathrm{C}\right)$. Cycling conditions and reaction mixes were as described in 'Amplification specificity and efficiency' above. Data were collected as $\mathrm{C}_{\mathrm{q}}$ values obtained after setting the threshold across the exponential phase of the amplification curve. Amplification efficiency and $\mathrm{C}_{\mathrm{q}}$ values of both target and reference genes were used as input data in the REST 2009 software (v. 2.0.13, Qiagen) developed for relative quantitation studies. The software applies a mathematical model that takes into account the PCR efficiencies of both the gene of interest and reference genes. The geometric mean of all reference gene concentrations is used to calculate the relative expression of target genes.

Genes of interest were separately normalised to the reference genes and then compared to the experimen- tal control samples (maintained at $27^{\circ} \mathrm{C}$ ) at each time point that were set as a calibrator. Results are expressed as gene expression fold changes relative to the calibrator. Significant differences between treated samples and controls were detected by the software through a hypothesis test for the difference between the samples (hypothesis $H_{1}$, significance for $\mathrm{p}\left(H_{1}\right)<$ 0.05 ) by performing up to 50000 random reallocations of treated samples and controls between the groups.

\section{RESULTS}

\section{Selection and validation of reference genes}

A total of 5 candidate genes from different functional classes that are commonly used as reference genes were chosen for the present study (Table 1). The panel includes genes encoding for 2 different rRNAs (mitochondrial: mtLSU, and ribosomal: rLSU), ubiquitin, actin and $\alpha$-tubulin. Primers were designed for all genes, and high specificity and reaction efficiency (Table 1) were confirmed through melting-point analysis and standard curves.

NormFinder analysis determined that the gene encoding for $\alpha$-tubulin was the single best reference, with a stability value of 0.052 . Also, $\alpha$-tubulin and ubiquitin were the most stable 2-candidate gene combination. However, the use of the 3 most stable internal control genes is strongly recommended by Vandesompele et al. (2002); hence the next most suitable gene, rLSU, was also included (Table 2).

\section{Gene expression profiles in Rhopaloeides odorabile exposed to temperature stress}

We assessed the effects of thermal stress on the expression of 6 functionally diverse genes (candidate biomarkers) in the marine sponge Rhopaloeides odorabile. All genes could be amplified with an optimal efficiency (ranging from 0.9 to 1.06; Table 1). Expres-

Table 2. Expression stability values of the candidate reference genes calculated using NormFinder algorithms. The best combination was found to be $\alpha$-tubulin and ubiquitin. The stability value for the best combination of 2 genes was found to be 0.033 . mtLSU: mitochondrial rRNA, rLSU: $28 \mathrm{~S}$ rRNA

\begin{tabular}{|lc|}
\hline Gene coding for & NormFinder stability value \\
\hline mtLSU & 0.162 \\
Actin & 0.096 \\
rLSU & 0.071 \\
Ubiquitin & 0.052 \\
$\alpha$-tubulin & 0.052 \\
\hline
\end{tabular}


sion data for each target gene were normalised to $\alpha$-tubulin, ubiquitin and rLSU, and then compared to the calibrator of each sampling point (Fig. 1).

All sponge clones survived for the whole length of the experiment except for specimens kept at $32^{\circ} \mathrm{C}$, which, after $3 \mathrm{~d}$, showed signs of necrosis and died.

In sponges treated at 31 and $32^{\circ} \mathrm{C}$, there was a significant reduction $\left(\mathrm{p}\left(H_{1}\right)<0.05\right)$ in expression of the genes encoding for arp2/3, FER and Hsp90 relative to the control after $1 \mathrm{~d}\left(54.6,69.2\right.$ and $66.6 \%$ at $31^{\circ} \mathrm{C}_{i} 73.7,76$ and $57.2 \%$ at $32^{\circ} \mathrm{C}$, respectively) and a further reduction in sponges kept at $31^{\circ} \mathrm{C}$ for $3 \mathrm{~d}(48.1,46.7$ and $64.5 \%$, respectively). In contrast, transcript levels of all 3 genes strongly increased after $3 \mathrm{~d}$ at $32^{\circ} \mathrm{C}(225.8$, 117.4 and $48.8 \%$, respectively). In sponges kept for $14 \mathrm{~d}$ at $31^{\circ} \mathrm{C}$, a decline in arp2/3, FER and Hsp90 transcript abundance was measured $(55.7,49.3$ and $48.6 \%$, respectively), and this down-regulation was maintained during the recovery period at $27^{\circ} \mathrm{C}(20.8,33.9$ and $32.8 \%$ for arp2/3, FER and Hsp90, respectively). The experimental treatment caused a reduction of $\mathrm{CaM}$ expression at both temperatures (ranging from 42.4 to $71.9 \%$ ), with a significant ( 87.4 and $71.1 \%$ ) down-regulation after $1 \mathrm{~d}$ at $32^{\circ} \mathrm{C}$ and $3 \mathrm{~d}$ at $31^{\circ} \mathrm{C}$, respectively. CaM transcript levels rose $(12.7 \%)$ during the $27^{\circ} \mathrm{C}$ recovery period. The molecular chaperone $H s p 40$ was slightly induced after $1 \mathrm{~d}$ at $31^{\circ} \mathrm{C}$ $(3.8 \%)$, only to be down-regulated for the rest of the experiment, although not significantly. A stronger induction was evident in specimens kept at $32^{\circ} \mathrm{C}$ : the Hsp40 gene transcript showed an 82.8 and $167 \%$ increase after 1 and $3 \mathrm{~d}$, respectively. $U b C$ gene expression was significantly reduced after $3 \mathrm{~d}$ at $31^{\circ} \mathrm{C}$ $(48.9 \%)$, and was slightly up-regulated $(2.4 \%)$ during the recovery period. A significant increase in expres- sion of UbC was detected in sponges maintained at $32^{\circ} \mathrm{C}$ for $3 \mathrm{~d}$ (Fig. 1).

It is worth noting that during the $24 \mathrm{~h}$ recovery period at $27^{\circ} \mathrm{C}$, all target genes became up-regulated from the previous time point, with values still lower but closer to the expression levels in the controls. Only the Hsp90 gene was significantly different from the control during the recovery period. CaM was the only gene that changed from a $40 \%$ down-regulation to $12 \%$ upregulation during the last day of the experiment.

\section{DISCUSSION}

The present study is the first to employ a range of putative stress-response genes to investigate the molecular-level effects of thermal stress in sponges and identify potential genetic biomarkers. The qPCR analysis indicated that sponges go through a general shut-down of molecular systems immediately after thermal stress, with a subsequent induction of the heat shock response system. Overall, a very strict thermal threshold between 31 and $32^{\circ} \mathrm{C}$ was identified for the sponge Rhopaloeides odorabile.

To assure reliable quantification of gene expression, we identified suitable reference genes among a panel of 5 commonly used 'housekeeping' genes. The gene coding for $\alpha$-tubulin was the best reference gene and the one coding for mtLSU was the least stable gene. In addition, even with stable expression of $\alpha$-tubulin and rLSU, NormFinder still determined that the addition of ubiquitin would be required for optimal normalisation. This is consistent with the findings of Vandesompele et al. (2002), who reported that the use of a single gene for normalisation resulted in relatively large errors and
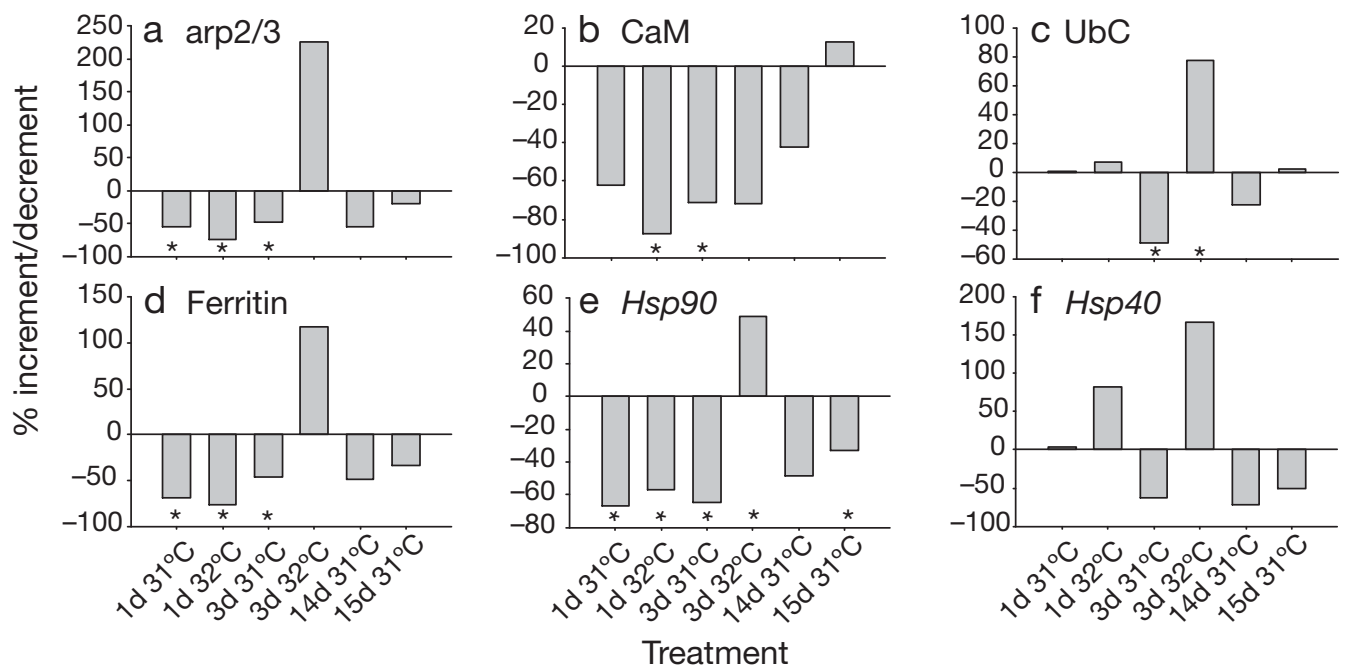

Fig. 1. Rhopaloeides odorabile. Gene expression variation in $R$. odorabile exposed to thermal stress for 1, 3, 14 or $15 \mathrm{~d}$ at 31 or $32^{\circ} \mathrm{C}$. (a) arp2/3: actin-related protein, (b) CaM: calmodulin, (c) UbC: ubiquitin-conjugating enzyme, (e) Hsp90: heat shock protein 90, (f) Hsp40: heat shock protein 40. *Significant difference from the relevant control for each treatment 
a minimum of 3 internal control genes was therefore recommended. Our results confirm that validation of multiple reference genes under the identical experimental conditions used for qPCR is essential to minimise error in data interpretation (Nicot et al. 2005, Ransbotyn \& Reusch 2006, Bustin et al. 2009).

In a previous study that assessed the effects of elevated seawater temperature on Rhopaloeides odorabile and its symbiotic microbial community, no visible stress effects were detected in sponges kept in $31^{\circ} \mathrm{C}$ water, but at $33^{\circ} \mathrm{C}$ sponges exhibited minor surface necrosis (10\% surface area) after $24 \mathrm{~h}$ and major necrosis (50 to $70 \%$ of surface area) after $3 \mathrm{~d}$ (Webster et al. 2008). In order to determine if sub-lethal stress was occurring in sponges exposed to elevated seawater temperatures prior to visual signs of necrosis, we assessed the expression of 6 functionally important genes previously reported to be involved in molecular stress response developing a multiple-gene profiling assay. A rapid decrease in the expression levels of the actin organiser $\operatorname{arp} 2 / 3$, the iron-storage protein FER, the signal-transducer CaM and the molecular chaperone Hsp90 at 31 and $32^{\circ} \mathrm{C}$ within the first $24 \mathrm{~h}$ indicates that the sponge goes through an initial shut-down of its molecular systems in response to thermal stress to suppress cellular activity. These results are consistent with previous studies showing suppression of transcription, protein biosynthesis and cell growth in different taxa (Yost \& Lindquist 1986, Duncan \& Hershey 1989, Bell et al. 1988). A change in gene expression and the suppression of around $10 \%$ of assayed genes, many of which are involved in protein synthesis and cell growth, was reported in the yeast Saccharomyces cerevisiae in response to a range of environmental stressors (Gasch et al. 2000). A general disruption of $\mathrm{Ca}^{2+}$ homoeostasis, cytoskeletal dynamics, calcification, metabolism and protein synthesis was observed by De Salvo et al. (2008) in the reef coral Montastraea faveolata exposed to thermal stress and bleaching; Voolstra et al. (2009) observed similar negative effects on the overall metabolism of $M$. faveolata embryos exposed to high temperature. In the goby Gillichthys mirabilis, hypoxia caused down-regulation of many cytoskeletal and ribosomal proteins, likely reflecting the reorganisation of metabolism and the suppression of major energyrequiring processes shortly after the onset of stress (Gracey et al. 2001). The reef fish Pomacentrus moluccensis reacted to heat stress with a suppression of cell growth, repression of transcriptional activity and an increase of protein breakdown (Kassahn et al. 2007). The reported gene-expression profiles obtained in response to stressors, the present study included, are consistent with an interpretation of metabolic re-organisation following the onset of stress, which would precede the induction of genes and de novo synthesis of proteins, which may ultimately allow the organism to cope with prolonged exposure to stress (Kassahn et al. 2007).

The rapid increase in expression of Hsp4O in sponges exposed to $32^{\circ} \mathrm{C}$ confirms the thermal stress effect, since the molecular chaperone system is activated in an attempt to preserve cellular functioning. The increased expression of $H s p 90$ after 3 d at $32^{\circ} \mathrm{C}$ indicates a slower activation of this heat shock response system but is also consistent with its role as a chaperone for directing degraded proteins to proteolysis. The increase of FER transcript levels after $3 \mathrm{~d}$ at $32^{\circ} \mathrm{C}$ indicates the presence of and the attempt to neutralise reactive oxygen species. This is consistent with previous observations of experimentally bleached corals (Császár et al. 2009). The significant up-regulation of the $\mathrm{UbC}$-encoding gene in the $32^{\circ} \mathrm{C}$-treated sponges after $3 \mathrm{~d}$ indicates a full activation of the proteasomemediated proteolytic system responsible for the degradation of damaged and unfolded proteins. A similar response was observed in the moon jellyfish Aurelia spp. upon exposure to tributyltin; in addition to the upregulation of genes coding for HSPs and their associated co-proteins, genes responsible for degradative and cell-shaping processes were also induced (Schroth et al. 2005). In sponges and corals, the extent of damage to essential cellular structures determines the balance between mortality and recovery (Halliwell \& Gutteridge 1989, Downs et al. 2002, López-Legentil et al. 2008). Even if minor damage can be repaired by an induction of the heat stress response (mediated by Hsp70 and other chaperones), greater damage can cause a collapse of the metabolic defence systems and the rapid death of the animal (Downs et al. 2002). Despite the fact that only a limited number of genes were investigated, our study results suggest that this sponge is equipped with the molecular tools to accommodate even minor temperature changes, the only limit to the survival of the species being the extent of the seawater warming. Further studies should investigate the ability of these animals to cope with lethal temperatures in relation to the rate of temperature increase.

The general pattern of down-regulation for most genes over the course of the temperature exposure indicates that both 31 and $32^{\circ} \mathrm{C}$ can cause physiological impairments in Rhopaloeides odorabile. The $32^{\circ} \mathrm{C}$ treatment likely represents an acute stress condition that activates the primary heat stress response together with secondary processes (such as degradative and cell-shaping processes and elimination of oxygen reactive species) (Blackstone 2001, Schroth et al. 2005). A similar phenomenon has also been reported in Aurelia spp. (Schroth et al. 2005) and in sponges exposed to cadmium (Schröder et al. 1999). The $31^{\circ} \mathrm{C}$ treatment is much less acute but appears to cause some 
sub-lethal molecular responses that are able to return to normal once the thermal stress has been removed.

The ability of marine organisms to adapt to and cope with temperature changes can be identified with laboratory experiments, so that responses to thermal changes in the natural environment can be explained or predicted. In the present study we assessed the ability of the Great Barrier Reef sponge Rhopaloeides odorabile to withstand seawater temperatures only 2 to $4^{\circ} \mathrm{C}$ above the in situ mean maximum annual temperature. Whereas sponges at $32^{\circ} \mathrm{C}$ only survived for the first $3 \mathrm{~d}$, specimens kept at $31^{\circ} \mathrm{C}$ for the whole length of the experiment did not show any signs of necrosis. Moreover, none of the genes in sponges kept at $31^{\circ} \mathrm{C}$ were significantly different to those in the $27^{\circ} \mathrm{C}$ controls after $14 \mathrm{~d}$. This indicates a very strict thermal threshold for $R$. odorabile between 31 and $32^{\circ} \mathrm{C}$ and is consistent with previous findings based on sponge necrosis and symbiotic disruptions in this species. These findings indicate that sponges may be as vulnerable as corals to changes in sea surface temperatures, and further research is required to determine the level of inter-species sensitivity to thermal stress and potential synergistic interactions with other water-quality stressors.

Acknowledgements. We thank E. Botte for insightful comments and scientific editing of the manuscript and $\mathrm{H}$. Luter for assistance in the field.

\section{LITERATURE CITED}

Andersen CL, Jensen JL, Ørntoft TF (2004) Normalization of real-time quantitative reverse transcription-PCR data: a model-based variance estimation approach to identify genes suited for normalization, applied to bladder and colon cancer data sets. Cancer Res 64:5245-5250

> Bachinski N, Koziol C, Batel R, Labura Z, Schröder HC, Müller WEG (1997) Immediate early response of the marine sponge Suberites domuncula to heat stress: reduction of trehalose and glutathione concentrations and glutathione S-transferase activity. J Exp Mar Biol Ecol 210: 129-141

Baker AC (2001) Ecosystems: reef corals bleach to survive change. Nature 411:765-766

Baker AC, Starger CJ, McClanahan TR, Glynn PW (2004) Coral reefs: corals' adaptive response to climate change. Nature 430:741

Bell JJ (2008) The functional roles of marine sponges. Estuar Coast Shelf Sci 79:341-353

Bell J, Neilson L, Pellegrini M (1988) Effect of heat shock on ribosome synthesis in Drosophila melanogaster. Mol Cell Biol 8:91-95

Blackstone NW (2001) Redox state, reactive oxygen species and adaptive growth in colonial hydroids. J Exp Biol 204: 1845-1853

Bustin SA (2000) Absolute quantification of mRNA using realtime reverse transcription polymerase chain reaction assays. J Mol Endocrinol 25:169-193
Bustin SA (2002) Quantification of mRNA using real-time reverse transcription PCR (RT-PCR): trends and problems. J Mol Endocrinol 29:23-39

Bustin SA, Benes V, Garson JA, Hellemans J and others (2009) The MIQE guidelines: minimum information for publication of quantitative real-time PCR experiments. Clin Chem 55:611-622

Császár NBM, Seneca FO, van Oppen MJH (2009) Variation in antioxidant gene expression in the scleractinian coral Acropora millepora under laboratory thermal stress. Mar Ecol Prog Ser 392:93-102

- De Salvo MK, Voolstra CR, Sunagawa S, Schwarz JA and others (2008) Differential gene expression during thermal stress and bleaching in the Caribbean coral Montastraea faveolata. Mol Ecol 17:3952-3971

$>$ Downs CA, Fauth JE, Halas JC, Dustan P, Bemiss J, Woodley CM (2002) Oxidative stress and seasonal coral bleaching. Free Radic Biol Med 33:533-543

Duncan RF, Hershey JW (1989) Protein synthesis and protein phosphorylation during heat stress, recovery, and adaptation. J Cell Biol 109:1467-1481

Eleutherio ECA, Araujo PS, Panek AD (1993) Protective role of trehalose during heat stress in Saccharomyces cerevisiae. Cryobiology 30:591-596

Feder ME, Hofmann GE (1999) Heat-shock proteins, molecular chaperones, and the stress response: evolutionary and ecological physiology. Annu Rev Physiol 61:243-282

Gasch AP, Spellman PT, Kao CM, Carmel-Harel O and others (2000) Genomic expression programs in the response of yeast cells to environmental changes. Mol Biol Cell 11: 4241-4257

> Glickman MH, Ciechanover A (2002) The ubiquitin-proteasome proteolytic pathway: destruction for the sake of construction. Physiol Rev 82:373-428

Goldberg AL (2003) Protein degradation and protection against misfolded or damaged proteins. Nature 426: 895-899

> Gracey AY, Troll JV, Somero GN (2001) Hypoxia-induced gene expression profiling in the euryoxic fish Gillichthys mirabilis. Proc Natl Acad Sci USA 98:1993-1998

> Gutierrez L, Mauriat M, Guénin S, Pelloux J and others (2008) The lack of a systematic validation of reference genes: a serious pitfall undervalued in reverse transcriptionpolymerase chain reaction (RT-PCR) analysis in plants. Plant Biotechnol J 6:609-618

Haller F, Kulle B, Schwager S, Gunawan B, von Heydebreck A, Sultmann H, Fuzesi L (2004) Equivalence test in quantitative reverse transcription polymerase chain reaction: confirmation of reference genes suitable for normalization. Anal Biochem 335:1-9

Halliwell B, Gutteridge JM (1989) Protection against oxidants in biological systems: the superoxide theory of oxygen toxicity. In: Halliwell B, Gutteridge JM (eds) Free radicals in biology and medicine. Clarendon Press, Oxford, p 86-179

> Harrison PM, Arosio P (1996) The ferritins' molecular properties, iron storage function and cellular regulation. Biochim Biophys Acta 1275:161-203

$>$ Hoegh-Guldberg O (1999) Climate change, coral bleaching and the future of the world's coral reefs. Mar Freshw Res 50:839-866

Hoegh-Guldberg O, Mumby PJ, Hooten AJ, Steneck RS and others (2007) Coral reefs under rapid climate change and ocean acidification. Science 318:1737-1742

Hofmann GE, Place SP (2007) Genomics-enabled research in marine ecology: challenges, risks and pay-offs. Mar Ecol Prog Ser 332:249-255 
Hottiger T, Schmutz P, Wiemken A (1987) Heat-induced accumulation and futile cycle of trehalose in Saccharomyces cerevisiae. J Bacteriol 169:5518-5522

Huggett J, Dheda K, Bustin S, Zumla A (2005) Real-time RTPCR normalization; strategies and considerations. Genes Immun 6:279-284

Hughes TP, Baird AH, Bellwood DR, Card M and others (2003) Climate change, human impacts and resilience of coral reefs. Science 301:929-933

Jarosová J, Kundu JK (2010) Validation of reference genes as internal control for studying viral infections in cereals by quantitative real-time RT-PCR. BMC Plant Biol 10: 146-154

Kassahn KS, Caley MJ, Ward AC, Connolly AR, Stone G, Crozier RH (2007) Heterologous microarray experiments used to identify the early gene response to heat stress in a coral reef fish. Mol Ecol 16:1749-1763

Kleypas JA, Buddemeier RW, Archer D, Gattuso JP, Langdon C, Opdyke BN (1999) Geochemical consequences of increased atmospheric carbon dioxide on coral reefs. Science 284:118-120

Krasko A, Scheffer U, Koziol C, Pancer Z, Batel R, Badria FA, Müller WEG (1997) Diagnosis of sublethal stress in the marine sponge Geodia cydonium: application of the $70 \mathrm{kDa}$ heat-shock protein and a novel biomarker, the Rab GDP dissociation inhibitor, as probes. Aquat Toxicol 37: 157-168

Li J, Qian X, Sha B (2009) Heat shock protein 40: structural studies and their functional implications. Protein Pept Lett 16:606-612

López-Legentil S, Song B, McMurray SE, Pawlik JR (2008) Bleaching and stress in coral reef ecosystems: hsp70 expression by the giant barrel sponge Xestospongia muta. Mol Ecol 17:1840-1849

Machesky LM, Gould KL (1999) The Arp2/3 complex: a multifunctional actin organizer. Curr Opin Cell Biol 11:117-121

Mieog JC, Van Oppen MJH, Berkelmans R, Stam WT, Olsen JL (2009) Quantification of algal endosymbionts (Symbiodinium) in coral tissue using real-time PCR. Mol Ecol Resour 9:74-82

Nicot N, Hausman JF, Hoffman L, Evers D (2005) Housekeeping genes selection for real time PCR normalization in potato during biotic and abiotic stress. J Exp Bot 56: 2907-2914

Perkins EJ, Lotufo GR (2003) Playing in the mud-using gene expression to assess contaminant effects on sediment dwelling invertebrates. Ecotoxicology 12:453-456

Picard D (2002) Heat-shock protein 90, a chaperone for folding and regulation. Cell Mol Life Sci 59:1640-1648

> Przeslawski R, Ahyong S, Byrne M, Wörheide G, Hutchings P (2008) Beyond corals and fish: the effects of climate change on non-coral benthic invertebrates of tropical reefs. Glob Change Biol 14:2773-2795

Ransbotyn V, Reusch TBH (2006) Housekeeping gene selection for quantitative real-time PCR assays in the seagrass Zostera marina subjected to heat stress. Limnol Oceanogr Methods 4:367-373

Rowan R (2004) Coral bleaching: thermal adaptation in reef coral symbionts. Nature 430:742
Rozen S, Skaletsky H (1999) Primer3 on the WWW for general users and for biologist programmers. In: Misener S, Krawetz SA (eds) Methods in molecular biology, Vol 132. Bioinformatics methods and protocols. Humana Press, New York, NY, p 365-396

Schallreuter KU, Gibbons NC, Zothner C, Abou Elloof MM, Wood JM (2007) Hydrogen peroxide-mediated oxidative stress disrupts calcium binding on calmodulin: more evidence for oxidative stress in vitiligo. Biochem Biophys Res Commun 360:70-75

Schröder HC, Hassanein HM, Lauenroth S, Koziol C and others (1999) Induction of DNA strand breaks and expression of HSP70 and GRP78 homolog by cadmium in the marine sponge Suberites domuncula. Arch Environ Contam Toxicol 36:47-55

> Schröder HC, Grebenjuk VA, Binder M, Skorokhod A, Batel R, Hassanein H, Müller WEG (2004) Functional molecular biodiversity: assessing the immune status of two sponge populations (Suberites domuncula) on the molecular level. PSZN I: Mar Ecol 25:93-108

Schroth W, Ender A, Schierwater B (2005) Molecular biomarkers and adaptation to environmental stress in moon jelly (Aurelia spp.). Mar Biotechnol 7:449-461

Smith CJ, Osborn AM (2009) Advantages and limitations of quantitative PCR (Q-PCR)-based approaches in microbial ecology. FEMS Microbiol Ecol 67:6-20

Suzuki T, Higgins PJ, Crawford DR (2000) Control selection for RNA quantitation. Biotechniques 29:332-333

Torti SV, Kwak EL, Miller SC, Miller LL and others (1988) The molecular cloning and characterization of murine ferritin heavy chain, a tumor necrosis factor-inducible gene. J Biol Chem 263:12638-12644

Vandesompele J, De Preter K, Pattyn F, Poppe B, Van Roy N, De Paepe A, Speleman F (2002) Accurate normalization of real-time quantitative RT-PCR data by geometric averaging of multiple internal control genes. Genome Biol 3:research0034.1-research0034.11 doi:10.1186/gb-20023-7-research0034

> Voolstra CR, Schnetzer J, Peshkin L, Randall CJ, Szmant AM, Medina M (2009) Effects of temperature on gene expression in embryos of the coral Montastraea faveolata. BMC Genomics 10:627 doi:10.1186/1471-2164-10-627

Wang X, Seed B (2006) High-throughput primer and probe design. In: Dorak MT (ed) Real-time PCR (BIOS-advanced methods series). Taylor \& Francis, Oxford, p 93-106

Watanabe K, Hamamura N (2003) Molecular and physiological approaches to understanding the ecology of pollutant degradation. Curr Opin Biotechnol 14:289-295

Webster NS, Cobb RE, Negri AP (2008) Temperature thresholds for bacterial symbiosis with a sponge. ISME $\mathrm{J} 2$ : 830-842

Yost HJ, Lindquist S (1986) RNA splicing is interrupted by heat shock and is rescued by heat shock protein synthesis. Cell 45:185-193

Zielinski RE (1998) Calmodulin and calmodulin-binding proteins in plants. Annu Rev Plant Physiol Plant Mol Biol 49:697-725

Submitted: November 26, 2010; Accepted: March 14, 2011 Proofs received from author(s): May 20, 2011
Editorial responsibility: Joseph Pawlik, Wilmington, North Carolina, USA 